\title{
High energy feeding in protein-energy malnutrition
}

\author{
O. G. BROOKE and ERICA F. WHEELER* \\ From the Tropical Metabolism Research Unit, Mona, Jamaica
}

\begin{abstract}
Brooke, O. G., and Wheeler, E. F. (1976). Archives of Disease in Childhood, 51, 968. High energy feeding in protein-energy malnutrition. The use of a highfat diet in malnourished children produced accelerated growth of lean tissues as well as adipose tissue, and resulted in rapid nutritional rehabilitation in 25 seriously malnourished babies. Such diets are easy to prepare and relatively cheap, and they offer important advantages over conventional feeding in the hospital treatment of malnourished children.
\end{abstract}

Dietary energy in excess of normal requirements must be provided to allow satisfactory recovery from malnutrition (Waterlow, 1961). This is because of the high energy cost of new tissue synthesis, both as stored energy and as energy consumed in oxidative synthetic processes (Kielanowski and Kotarbińska, 1969). A number of high energy regimens have been described for oral feeding in malnourished infants (Graham, Cordano, and Baertl, 1963; Wharton, 1967; Rutishauser and McCance, 1968; Alvarado, Viteri, and Béhar, 1970; Kerr et al., 1973). In the Tropical Metabolism Research Unit a high-fat diet has been used with success over a period of years for treatment of marasmus and kwashiorkor (Ashworth, 1969). This produces greatly enhanced weight gain (Ashworth et al., 1968; Ashworth, 1969), partly due to the rapid restoration of depleted fat stores (Kerr et al., 1973; Wheeler, 1974). Since high-fat diets are easy to prepare and relatively cheap they may represent the best approach to the treatment of the established case of malnutrition, provided they can be shown to produce balanced growth and not simply a disproportionate increase in adipose tissue. There is evidence from studies of total-body potassium (TBK) that they do (Ashworth, 1969). However, the relation between TBK and lean body mass during the early course of nutritional recovery is not always certain, because of the frequency of specific potassium deficiency (Alleyne, 1970a). We present some further data to show that a highfat diet produces a satisfactory general increase in growth in malnourished babies.

Received 17 March 1976.

*Present address: Dept. of Human Nutrition, London School of Hygiene and Tropical Medicine, Keppel St., London WC1.

\section{Patients and methods}

Patients. Data are presented on 25 unselected admissions ( 15 boys, 10 girls) to the Tropical Metabolism Research Unit all of whom were seriously malnourished. According to the Wellcome Trust Working Party definitions (Lancet, 1970), 6 had kwashiorkor, 7 had marasmic-kwashiorkor, and 12 were marasmic. Mean age on admission was $1 \cdot 17$ years (range $0 \cdot 5-2 \cdot 75$ ).

Nutritional management. A standard regimen of graded feeding was followed in all children (Garrow, Picou, and Waterlow, 1962). During the first week this was flexible according to the needs of the individual child. Initial feeding was either a maintenance diet of dried skim milk, oil, and glucose, or dilute cows' milk, or glucose/electrolyte solution, depending on the severity of diarrhoea. The rate of grading ensured that the children were receiving the high-fat diet by the end of the second week, and usually before. Feed volumes of $30 \mathrm{ml} / \mathrm{kg}$ or more were offered 4-hourly. All children received supplements of potassium, magnesium, iron, and vitamins.

High energy diet. This consisted of a proprietary milk (Pelargon, Nestlé) to which was added arachis oil to give a theoretical energy yield of $565 \mathrm{~kJ} / 100 \mathrm{ml}$ $(135 \mathrm{kcal})$. The final mixture had $9 \%$ protein energy. Arachis oil was used because it was readily available and cheap. It is about $75 \%$ unsaturated, the fatty acids being predominantly oleic and linoleic. The composition of the feed is given in Table I. It was made up by adding the oil to a paste of moistened milk powder in a domestic blender and homogenizing for 10-15 minutes before reconstituting to full volume with water. This ensured that the fat remained dispersed in the milk for several hours. In practice not all of the measured volume of fat was ever incorporated in the feed, and analysis by bomb calorimetry (Spady, 1974) has given energy values between 493 and $547 \mathrm{~kJ} / 100 \mathrm{ml}(118$ and $131 \mathrm{kcal})$. The majority of the children achieved 
TABLE I

Preparation

\begin{tabular}{lr}
\hline Dried full-cream milk & \\
Arachis oil (g) & 190 \\
Energy (kJ) & 60 \\
Protein (g) & 5940 \\
& 31
\end{tabular}

*Pelargon (Nestlé) - a proprietary preparation containing maize starch, dextrin-maltose and sucrose; total carbohydrate $570 \mathrm{~g} / \mathrm{kg}$, fat $170 \mathrm{~g} / \mathrm{kg}$, protein $165 \mathrm{~g} / \mathrm{kg}$.

Conversion-SI units to traditional: Energy: $4 \cdot 18 \mathrm{~kJ} \approx 1 \mathrm{kcal}$.

intakes in excess of $830 \mathrm{~kJ} / \mathrm{kg}$ per day $(199 \mathrm{kcal})$ on this diet, which is in routine use in this unit.

Measurement of growth. Weight was measured to the nearest $5 \mathrm{~g}$ on a beam balance. Crown-heel length was measured to the nearest $0.25 \mathrm{~cm}$ on a horizontal stadiometer. Occipitofrontal and mid-upper arm circumferences were measured to the nearest $\mathrm{mm}$ with fibreglass tape. All measurements were made by the same trained nursing staff at daily or weekly intervals. Skinfold thickness measurements were made weekly by the authors at the biceps, triceps, subscapular, and suprailiac sites (Jelliffe, 1966) using Harpenden calipers. Arm muscle area was derived from mid-upper arm circumference and triceps skinfolds (Standard, Wills, and Waterlow, 1959) using a nomogram devised by Gurney (Gurney and Jelliffe, 1973). Total body potassium was measured at weekly intervals in 15 of the children using the Packard 4 pi liquid scintillation whole body counter (Garrow, 1965).

\section{Results}

We have only considered growth during the first 7 weeks of nutritional rehabilitation since after this time the children had recovered much of their weight deficit and would normally be changed to mixed diet. Mean daily intake between the 14th and 49th day was $978 \mathrm{~kJ} / \mathrm{kg}$, SD $86(234 \mathrm{kcal} /$ $\mathrm{kg}$, SD 21), assuming that the average energy content of the feed was $520 \mathrm{~kJ} / 100 \mathrm{ml}(124 \mathrm{kcal})$ (Spady, 1974).

Table II shows the changes in the various measurements during the 7-week period and their relation to normal standards where available. Weight, skinfold thickness, arm muscle area, and TBK were relatively severely affected; length and head circumference much less so. Mean weight in the malnourished state was only $55 \%$ of expected weight for age and $70 \%$ of expected weight for length. Skinfolds were half the normal thickness for age, and some of the children had negligible amounts of subcutaneous fat, with skinfolds reduced below $3 \mathrm{~mm}$ in many instances. TBK was very low on admission, resulting from specific potassium depletion as well as from reduced muscle mass. The well-maintained head size and relatively unaffected length reflect the acute nature of severe protein-energy malnutrition in most Jamaican children, who are at greatest risk in the period immediately after weaning (Alleyne, 1970b).

After 7 weeks' treatment, catch-up growth was far advanced in all the measurements, being particularly striking in the skinfolds. However, there were large gains in lean tissues, with TBK increasing by $90 \%$ and arm muscle area rising to within $2 \mathrm{SD}$ of normal for age. Mean head growth during the treatment period was $1.9 \mathrm{~cm}$, compared with an expected gain of $0.75 \mathrm{~cm}$, an increase of $150 \%$.

TABLE II

Changes in various measurements of growth during 7 weeks of high energy feeding in 25 malnourished children, compared with normal values for children of the same age

\begin{tabular}{|c|c|c|c|c|c|c|}
\hline & \multirow{2}{*}{$\begin{array}{l}\text { Average normal } \\
\text { for age } 1 \cdot 17 \mathrm{yr}\end{array}$} & \multicolumn{2}{|c|}{$\begin{array}{l}\text { On admission } \\
\text { (mean age } 1 \cdot 17 \mathrm{yr} \text { ) }\end{array}$} & \multirow{2}{*}{$\begin{array}{l}\text { Average normal } \\
\text { for age } 1 \cdot 3 \mathrm{yr}\end{array}$} & \multicolumn{2}{|c|}{$\begin{array}{c}\text { Treated } \\
\text { (mean age } 1 \cdot 3 \mathrm{yr})\end{array}$} \\
\hline & & Mean \pm SD & $\begin{array}{c}\% \text { of } \\
\text { normal }\end{array}$ & & Mean \pm SD & $\%$ of normal \\
\hline $\begin{array}{l}\text { Weight (kg) } \\
\text { Crown-heel length (cm) } \\
\text { Head circumference (cm) } \\
\text { Biceps skin fold (mm) } \\
\text { Triceps skinfold (mm) } \\
\text { Subscapular skinfold (mm) } \\
\text { Suprailiac skinfold (mm) } \\
\text { Mid-upper arm } \\
\text { circumference (cm) } \\
\text { Arm muscle area (cm²) } \\
\text { Total body potassium } \\
\text { (mmol) }\end{array}$ & $\begin{array}{c}10 \cdot 56^{\star} \\
77 \cdot 5^{\star} \\
46 \cdot 7 \dagger \\
10 \cdot 3 \ddagger \\
7 \cdot 9 \$\end{array}$ & $\begin{array}{r}5 \cdot 79 \pm 1 \cdot 2 \\
67 \cdot 8 \pm 5 \cdot 6 \\
42 \cdot 1 \pm 2 \cdot 1 \\
4 \cdot 1 \pm 1 \cdot 4 \\
5 \cdot 5 \pm 2 \cdot 6 \\
3 \cdot 4 \pm 1 \cdot 0 \\
3 \cdot 8 \pm 1 \cdot 9 \\
10 \cdot 8 \pm 1 \cdot 3 \\
6 \cdot 8 \pm 1 \cdot 9 \\
199 \pm 50\end{array}$ & $\begin{array}{l}55 \\
87 \\
90 \\
\\
53 \\
43 \\
\\
\\
68 \\
54 \\
41\end{array}$ & $\begin{array}{l}10 \cdot 90^{\star} \\
79 \cdot 2^{\star} \\
46 \cdot 9 \dagger \\
10 \cdot 3 \ddagger \\
7 \cdot 7 \S \\
\\
16 \cdot 0 \ddagger \\
12 \cdot 7 \ddagger \\
499 \mid j\end{array}$ & $\begin{array}{r}8 \cdot 43 \pm 1 \cdot 4 \\
70 \cdot 3 \pm 5 \cdot 1 \\
44 \cdot 0 \pm 1 \cdot 7 \\
6 \cdot 5 \pm 1 \cdot 1 \\
10 \cdot 2 \pm 2 \cdot 6 \\
7 \cdot 5 \pm 1 \cdot 2 \\
9 \cdot 8 \pm 3 \cdot 9 \\
14 \cdot 3 \pm 1 \cdot 5 \\
9 \cdot 9 \pm 2 \cdot 5 \\
367 \pm 47\end{array}$ & $\begin{array}{l}77 \\
89 \\
94 \\
\\
99 \\
97\end{array}$ \\
\hline
\end{tabular}

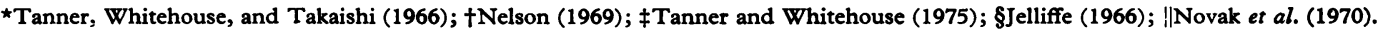




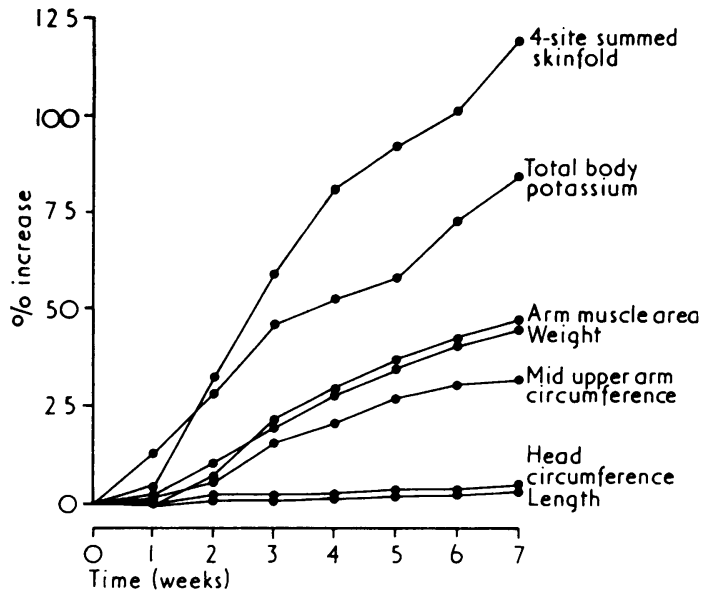

FIG. 1.-Percentage increase in various measurements of growth during 7 weeks of high energy diet in 25 malnourished children.

Height-age increased by 8.8 weeks during the 7-week period.

Fig. 1 shows the percentage increase in the various measurements at weekly intervals during treatment. An increase of $120 \%$ in the summed skinfold reflects the severe depletion of fat stores initially. The relatively large increase in TBK during the first 3 weeks is probably due to the early restoration of specific potassium deficits as well as to growth of lean tissues. Increase in arm muscle area exactly parallels that of weight during the entire period.

Early feeding was more difficult in the children with kwashiorkor than in those with marasmus or marasmic-kwashiorkor, and tube feeds were often necessary in the first week because of anorexia. Vomiting was not usually a serious problem. All the oedematous children had lost their oedema by the end of the second week of treatment, and the onset of diuresis was usually accompanied by a marked improvement in appetite and general wellbeing. Fig. 2 shows the changes in bodyweight in the three categories of malnutrition. The children with kwashiorkor did not pass their admission weight until the third week of treatment, but thereafter gained weight at much the same rate as those with marasmus and marasmic-kwashiorkor. The marasmic children showed a particularly marked weight gain during the second and third weeks of treatment, which was associated with large gains in subcutaneous fat.

\section{Discussion}

Although it is possible for malnourished children to recover their deficits when given conventional

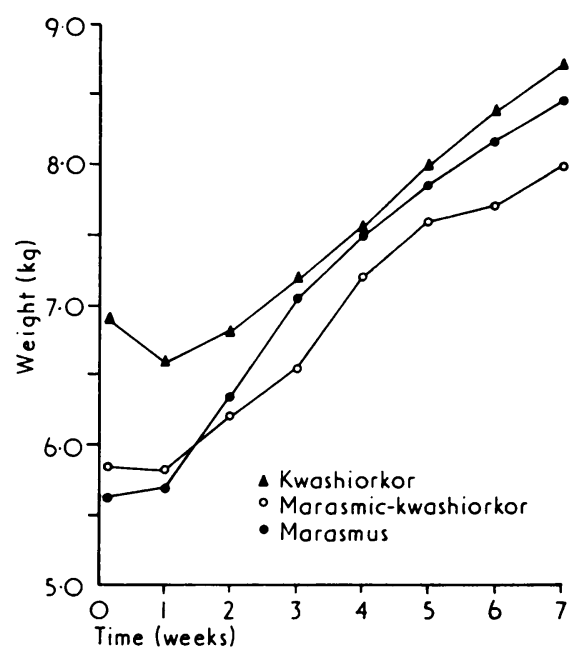

FIG. 2.-Changes in body weight during treatment in children with marasmus, kwashiorkor, and marasmickwashiorkor.

diets, the process must inevitably be prolonged. From regressions of weight gain vs. energy intake (Ashworth et al., 1968; Kerr et al., 1973), each gram of tissue gained is associated with an additional intake of approximately $30 \mathrm{~kJ}(7 \cdot 2 \mathrm{kcal})$. A deficit of $4.8 \mathrm{~kg}$, as in these babies, might be expected to require a total intake of $140000 \mathrm{~kJ}$ (33 $493 \mathrm{kcal}$ ) above maintenance for its correction. A diet of conventional milk providing $270 \mathrm{~kJ} / 100$ $\mathrm{ml}$ ( $65 \mathrm{kcal}$ ) given 4-hourly at $30 \mathrm{ml} / \mathrm{kg}$ would supply enough surplus energy to meet this requirement in about 280 days, as opposed to the 50-60 days actually taken on high energy feeding. Furthermore, though malnourished children fed ad libitum regulate their intake to some extent according to the energy content of their diet, they do not increase their volume intake sufficiently when changed from high energy to standard milk to maintain the level of their previous energy intake (Ashworth, 1974), and their growth rate falls. The high efficiency of fat as a source of energy means that conventional feed volumes can still provide large energy intakes, and this has evident advantages in the treatment of malnutrition, particularly in understaffed units where round-the-clock feeding may not be practicable.

The provision of a high energy intake does not necessarily mean that the increased energy will be available for growth. A high-fat diet could result in fat malabsorption, or alternatively in the absorption of fat which is stored in the liver or adipocytes without contributing to the energy needs of balanced growth. In spite of the damage to the intestinal 
mucosa which is known to occur in severe malnutrition (Stanfield, Hutt, and Tunnicliffe, 1965), fat malabsorption is not usually a problem (McCance, Rutishauser, and Boozer, 1970). Measurement of faecal energy in babies on high-fat feeding in this unit has shown losses of the order of $10 \%$ of the dietary intake (Brooke and Cocks, unpublished data; Spady, 1974). and it is rare for the children to have visibly abnormal stools.

The early and rapid increase in skinfold thickness which occurred in the babies described in this paper indicates that much dietary fat was being stored, and it is probable that tissue deposited during the early recovery period has a higher fat content than it does in a normal child of the same age (Kerr et al., 1973; Wheeler, 1974). If this is so it presumably reflects the relatively greater deficit of fat than other tissues in the malnourished child. The accelerated growth of lean tissues in our children indicates that surplus energy is available as fuel for synthetic processes other than those necessary for the formation of adipose tissue. There is no evidence that dietary fat is stored in the liver during recovery; gross fatty liver may occur as a feature of kwashiorkor in Jamaica (Waterlow, 1948) but the fat is rapidly cleared after the introduction of a high quality diet (Waterlow, Cravioto, and Stephen, 1960).

The preparation of a high-energy diet is simple, and there is good evidence not only that it shortens the period of recovery from malnutrition, but also that it is virtually impossible for recovery to take place on a normal energy intake, such as is provided by enriched milk. However, it is important to preserve the correct balance between energy and protein. We have indicated that an energy content of about $550 \mathrm{~kJ} / 100 \mathrm{ml}(130 \mathrm{kcal} / 100 \mathrm{ml})$ is needed, with protein contributing about $8 \%$ of the total energy. The cheapest locally available milk powders and oil can be used, with the addition of skimmed milk powder and sugar if desired, so long as the final protein-energy levels are satisfactory.

\section{REFERENCES}

Alleyne, G. A. O. (1970a). Studies on total body potassium in malnourished infants. British fournal of Nutrition, 24, 205.

Alleyne, G. A. O. (1970b). Some features of infantile malnutrition in Jamaica. West Indian Medical fournal, 19, 32.

Alvarado, J., Viteri, F., and Béhar, M. (1970). Tratamiento hospitalano de la desnutrición proteinico calórica severa. Revista Colegio médico de Guatemala, 21, 231.

Ashworth, A. (1969). Growth rates in children recovering from protein-calorie malnutrition. British fournal of Nutrition, 23, 835.

Ashworth, A. (1974). Ad lib. feeding during recovery from malnutrition. British fournal of Nutrition, 31, 109.
Ashworth, A., Bell, R., James, W. P. T., and Waterlow, J. C. (1968). Calorie requirements of children recovering from proteincalorie malnutrition. Lancet, 2, 600.

Garrow, J. S. (1965). The use and calibration of a small whole-body counter for the measurement of total body potassium in malnourished infants. West Indian Medical fournal, 14, 73.

Garrow, J. S., Picou, D., and Waterlow, J. C. (1962). The treatment and prognosis of infantile malnutrition in Jamaican children. West Indian Medical fournal, 11, 217.

Graham, G. G., Cordano, A., and Baertl, J. M. (1963). Studies in infantile malnutrition. II. Effect of protein and calorie intake on weight gain. Fournal of Nutrition, 81, 249.

Gurney, J. M., and Jelliffe, D. B. (1973). Arm anthropometry in nutritional assessment: nomogram for rapid calculation of muscle circumference and cross-sectional muscle and fat areas. American Fournal of Clinical Nutrition, 26, 912.

Jelliffe, D. B. (1966). The Assessment of the Nutritional Status of the Community. Monograph no. 53. WHO, Geneva.

Kerr, D. S., Ashworth, A., Picou, D., Poulter, N., Seakins, A., Spady, D. W., and Wheeler, E. F. (1973). Endocrine Aspects of Malnutrition: Kroc Foundation Symposia No. 1. Ed. by L. I. Gardner and P. Amacher. Kroc Foundation, Santa Ynez, California.

Kielanowski, J., and Kotarbińska, M. (1969). Energy requirements of growing pigs. Proceedings of the Eighth International Congress of Nutrition, p. 742. Ed. by J. Mašek, K. Ołancová, and D. P. Cuthbertson. International Congress Series No. 213. Excerpta Medica, Amsterdam.

Lancet (1970). Annotation, 2, 302.

McCance, R. A., Rutishauser, I. H. E., and Boozer, C. N. (1970). The effect of kwashiorkor on the absorption and excretion of $\mathbf{N}$, fat, and minerals. Archives of Disease in Childhood, 45, 410.

Nelson, W. E. (1969). Textbook of Pediatrics, 9th ed., p. 48. Ed. by W. E. Nelson, V. C. Vaughan, and R. J. McKay. Saunders, Philadelphia.

Novak, L. P., Hamamoto, K., Orvis, A. L., and Burke, E. C. (1970). Total body potassium in infants. American fournal of Diseases of Children, 119, 419.

Rutishauser, I. H. E., and McCance, R. A. (1968). Calorie requirements for growth after severe undernutrition. Archives of Disease in Childhood, 43, 252.

Spady, D. W. (1974). Energy balance during recovery from malnutrition. MSc. thesis, London University.

Standard, K. L., Wills, V. G., and Waterlow, J. C. (1959). Indirect indicators of muscle mass in malnourished infants. American fournal of Clinical Nutrition, 7, 271.

Stanfield, J. P., Hutt, M. S. R., and Tunnicliffe, R. (1965). Intestinal biopsy in kwashiorkor. Lancet, 2, 519.

Tanner, J. M., and Whitehouse, R. H. (1975). Revised standards for triceps and subscapular skinfolds in British children. Archives of Disease in Childhood, 50, 142.

Tanner, J. M., Whitehouse, R. H., and Takaishi, M. (1966). Standards from birth to maturity for height, weight, height velocity and weight velocity: British children 1965 . I. and II. Archives of Disease in Childhood, 41, 454 and 613.

Waterlow, J. C. (1948). Fatty Liver Disease in Infants in the British West Indies. Special report of the Medical Research Council (London), no. 263. H.M.S.O., London.

Waterlow, J. C. (1961). The rate of recovery of malnourished infants in relation to the protein and calorie levels of the diet. fournal of Tropical Paediatrics, 7, 16.

Waterlow, J. C., Cravioto, J., and Stephen, J. M. L. (1969). Protein malnutrition in man. Advances in Protein Chemistry, 15, 131.

Wharton, B. A. (1967). Calorie Deficiencies and Protein Deficiencies, p. 147. Ed. by R. A. McCance and E. M. Widdowson. Churchill, London.

Wheeler, E. F. (1974). Changes in anthropometric measurements of children recovering from protein-energy malnutrition. Proceedings of the Nutrition Society, 34, 35A.

Correspondence to Dr. O. G. Brooke, Department of Child Health, St. George's Hospital Medical School, Blackshaw Road, Tooting, London SW17 OQT. 